\title{
ASSESSMENT OF VITAMIN D STATUS IN CZECH CHILDREN
}

\author{
Lenka Sochorová1, Lenka Hanzlíková1, Milena Černá1, ${ }^{3}$, Michala Vosátková2, Anna Pinkr Grafnetterová1, \\ Alena Fialová', ${ }^{1,}$ Rủžena Kubínová ${ }^{1}$ \\ ${ }^{1}$ National Institute of Public Health, Prague, Czech Republic \\ ${ }^{2}$ Institute of Endocrinology, Prague, Czech Republic \\ ${ }^{3}$ Third Faculty of Medicine, Charles University, Prague, Czech Republic
}

\section{SUMMARY}

Objective: Vitamin D deficiency is a global health problem. The aim of this study was to determine the proportion of Czech children with vitamin $D$ deficiency and examine related factors.

Methods: The study subjects were 419 healthy children aged 5 and 9 years. Severe vitamin $D$ deficiency was defined as a serum 25(OH)D level of $<25 \mathrm{nmol} / \mathrm{L}$ ( $3 \%$ of children), deficiency as that of $25-50 \mathrm{nmol} / \mathrm{L}$ ( $24 \%$ of children), insufficiency as that of $50-75 \mathrm{nmol} / \mathrm{L}$ ( $40 \%$ of children) and sufficiency as that of $>75 \mathrm{nmol} / \mathrm{L}$ ( $34 \%$ of children).

Results: Serum $25(\mathrm{OH}) \mathrm{D}$ levels varied mainly with season. The highest levels of $25(\mathrm{OH}) \mathrm{D}$ were reached in autumn (median: $79.0 \mathrm{nmo} / \mathrm{L}$ ), followed by summer (median: $67.8 \mathrm{nmol} / \mathrm{L}$ ) and winter (median: $56.0 \mathrm{nmol} / \mathrm{L})$. The lowest median value $(49.8 \mathrm{nmol} / \mathrm{L}$ ) was detected in spring.

Conclusion: Children with sufficiency $25(\mathrm{OH}) \mathrm{D}$ levels were more frequently exposed to the sun and exposed a larger part of their body to the sun while spending time outdoors. Levels of $25(\mathrm{OH}) \mathrm{D}$ were also associated with using vitamin D supplements within six weeks before sampling.

Key words: vitamin D, 25(OH)D levels, human biomonitoring, children, Czech Republic

Address for correspondence: M. Černá, National Institute of Public Health, Šrobárova 48, 10000 Prague 10, Czech Republic. E-mail: milena. cerna@szu.cz

https://doi.org/10.21101/cejph.a5386

\section{INTRODUCTION}

Human biomonitoring is a useful tool for assessing the levels of toxic substances ingested into the body from the environment as well as for evaluating the levels of several substances essential to health. In the Czech Republic, there has existed since 1991 a human biomonitoring network that functions as part of the Environmental Health Monitoring System that was established by the Czech Government. Over the years, monitoring has undergone major developmental stages which have improved its functioning (1). In 2016, it was decided to include vitamin $\mathrm{D}$ as a new biomarker into the ongoing Czech Human Biomonitoring System. Until now, there have been conducted only a few studies on vitamin D serum levels in the Czech population (2). Vitamin D plays an important role in calcium homeostasis maintenance and bone health. It also has been reported as a relevant factor in decreasing the risk of many chronic conditions, such as cardiovascular diseases, autoimmune diseases, metabolic disorders and others (3-5). The main objective of the present study was to assess vitamin D saturation in the population of Czech children and possible effects of certain factors (season, personal behaviour, etc.) on serum vitamin $\mathrm{D}$ concentration.

\section{MATERIALS AND METHODS}

\section{Sample Collection and Preparation}

A total of 419 blood samples were collected from healthy children aged 5 and 9 years to obtain serum for vitamin D analysis. The study was conducted in five Czech cities - Prague, Ostrava, Liberec, Žd'ár nad Sázavou, and Kutná Hora from March through December in 2016 and in January and February of 2017. The monitoring took place during regular medical check-ups of children aged 5 and 9 in surgeries of collaborating paediatricians. The children were enrolled in the study consecutively as they presented for check-ups according to the month of birth. Their parents signed an appropriate informed consent form and filled out a questionnaire about the child's socio-demographic characteristics and general lifestyle factors, including the length of sun exposure expressed in hours per day.

Blood samples were collected by trained nurses either during the preventive paediatric check-ups or at a designated department of medical laboratories. Serum was separated by centrifugation, frozen, transported to the analytical laboratory and stored at $-20^{\circ} \mathrm{C}$ until analysis. The vitamin D (25OHD total $-25 \mathrm{OHD} 2+25 \mathrm{OHD} 3)$ level was measured by the electrochemilu- 
minescence immunoassay (ECLIA) method (Cobas 6000, Roche, Manheim, Germany, IVD-CE). Analyses were performed in an accredited laboratory in compliance with the standard operating procedures and quality assurance and quality control (QA/QC) protocols. The study protocol was approved by the Ethical Committee of the National Institute of Public Health.

\section{Requirements for Vitamin D Threshold}

As reported by Pludowski, the majority of studies include $25(\mathrm{OH}) \mathrm{D}$ levels in the range of $75-125 \mathrm{nmol} / \mathrm{L}$ as the necessary minimal concentration for human well-being (6). However, in children, it is important to note that there are sparse outcome data to help define a healthy or optimal level of $25(\mathrm{OH}) \mathrm{D}(7)$. Vitamin D status was categorized as deficient $(<25 \mathrm{nmol} / \mathrm{L})$, insufficient $(<50$ $\mathrm{nmol} / \mathrm{L})$, sufficient $(<75 \mathrm{nmol} / \mathrm{L})$, and optimal $(\geq 75 \mathrm{nmol} / \mathrm{L})(8)$.

\section{Statistical Analyses}

The time when samples were collected was reported only as to the season of the year, namely spring, summer, autumn or winter, defined as March, April and May for spring, June, July and August for summer, September, October and November for autumn, and December, January and February for winter.

Differences between the 25(OH)D levels were tested using the Kruskal-Wallis test or Mann-Whitney U test. Statistical significance was set as $\alpha=0.05$. Data were processed using SPSS ver. 23 (SPSS Inc. Chicago, IL).

\section{RESULTS}

Table 1 shows the baseline characteristics of the studied children. Table 2 indicates that the level of $25(\mathrm{OH}) \mathrm{D}$ was measured in 419 serum samples and that the levels detected ranged between $12.1 \mathrm{nmol} / \mathrm{L}$ and $146.5 \mathrm{nmol} / \mathrm{L}$, with a median value of 63.0 $\mathrm{nmol} / \mathrm{L}$. The highest level of $25(\mathrm{OH}) \mathrm{D}$ was reached in the autumn (median: $79.0 \mathrm{nmol} / \mathrm{L}$ ) and was followed by those in the summer (median: $67.8 \mathrm{nmol} / \mathrm{L}$ ) and winter (median: $56.0 \mathrm{nmol} / \mathrm{L}$ ). The lowest median value $(49.8 \mathrm{nmol} / \mathrm{L})$ was detected in the spring (Fig. 1). On average, only $34 \%$ of children in our study group reached the optimal serum concentrations of $25(\mathrm{OH}) \mathrm{D}$. Significant

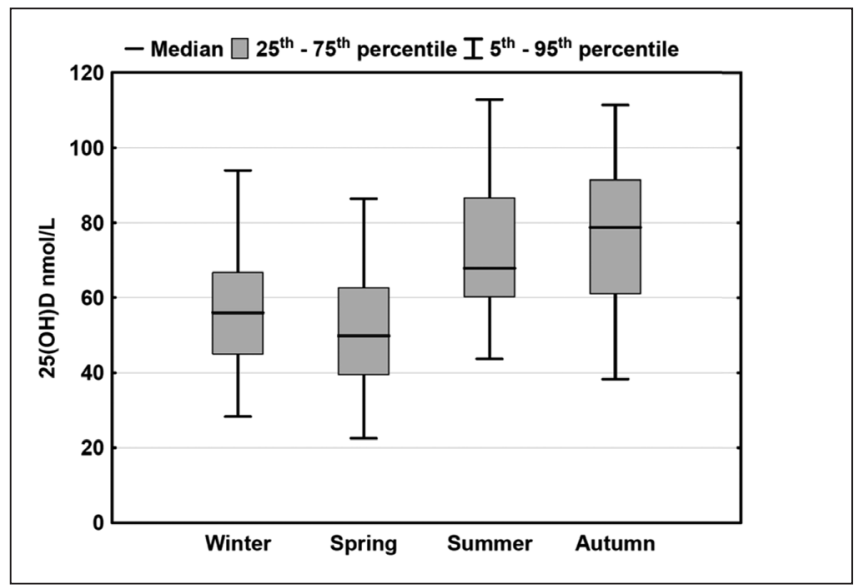

Fig. 1. $25(\mathrm{OH}) \mathrm{D}$ concentrations by season.
Table 1. Descriptive statistics of the participants enrolled in the study $(N=419)$

\begin{tabular}{|c|c|}
\hline Demographic characteristic & $\mathrm{n}(\%)$ \\
\hline \multicolumn{2}{|l|}{ Age (years) } \\
\hline 5 & $161(38.4)$ \\
\hline 9 & $256(61.1)$ \\
\hline Not specified & $2(0.5)$ \\
\hline \multicolumn{2}{|l|}{ Gender } \\
\hline Boys & $227(54.2)$ \\
\hline Girls & $185(44.2)$ \\
\hline Not specified & $7(1.6)$ \\
\hline \multicolumn{2}{|l|}{ Locality } \\
\hline Kutná Hora & $34(8.1)$ \\
\hline Ždár nad Sázavou & $99(23.6)$ \\
\hline Ostrava & $105(25.1)$ \\
\hline Liberec & $82(19.6)$ \\
\hline Prague & $99(23.6)$ \\
\hline \multicolumn{2}{|l|}{ Maternal education } \\
\hline Primary (ISCED 0-2) & $89(22.2)$ \\
\hline Secondary (ISCED 3-4) & $185(44.2)$ \\
\hline Tertiary (ISCED 5-6) & $128(30.5)$ \\
\hline Not specified & $17(4.1)$ \\
\hline \multicolumn{2}{|l|}{ Season of sample collection } \\
\hline Spring & $124(29.6)$ \\
\hline Summer & $85(20.3)$ \\
\hline Autumn & $144(34.4)$ \\
\hline Winter & $66(15.8)$ \\
\hline \multicolumn{2}{|l|}{ Vitamin D supplementation } \\
\hline Yes & $58(13.8)$ \\
\hline No & $240(57.3)$ \\
\hline Not specified & $121(28.9)$ \\
\hline
\end{tabular}

ISCED - International Standard Classification of Education

differences in $25(\mathrm{OH}) \mathrm{D}$ were observed depending on sampling season $(\mathrm{p}<0.001)$. Nevertheless, even in the autumn, when the levels are generally higher, altogether $44 \%$ of the children did not have the sufficiency level of 25(OH)D.

In this study, parents were asked several questions related to their child's sun exposure. Generally, the median serum concentrations of 25(OH)D were significantly higher in children who were frequently exposed to the sun in the last six weeks before sampling (median: $74.1 \mathrm{nmol} / \mathrm{L}$ versus $60.0 \mathrm{nmol} / \mathrm{L} ; \mathrm{p}<0.001$ ) and in those who exposed a larger part of their body (arms and face versus most of the body) to the sun while spending time outdoors (median: 60.7 $\mathrm{nmol} / \mathrm{L}$ versus $70.5 \mathrm{nmol} / \mathrm{L} ; \mathrm{p}<0.001)$. The level of $25(\mathrm{OH}) \mathrm{D}$ was also associated with using vitamin $\mathrm{D}$ dietary supplements within six weeks before sampling. Children who had used (according to the questionnaire) vitamin D-containing supplements had a median 25(OH)D concentration of $74.2 \mathrm{nmol} / \mathrm{L}$ compared with 62.0 $\mathrm{nmol} / \mathrm{L}$ in non-users $(\mathrm{p}>0.05)$. In terms of skin types, we selected the first five categories according to the Fitzpatrick classification (9); however, this factor was not significant $(\mathrm{p}>0.05)$ in our study. 
Differences in the 25(OH)D values on the borderline of significance $(p=0.05)$ were detected between children whose mothers have tertiary education (a slightly higher median of $67.6 \mathrm{nmol} / \mathrm{L}$ ) and those whose mothers have primary or secondary education (median of $61.9 \mathrm{nmol} / \mathrm{L}$ ). The maternal education level could also have an impact on food choices; more educated mothers might buy more marine oily fish, such as mackerel and salmon with increased content of vitamin D.

No statistical difference was found in the distribution by age, gender or place of residence between the study groups. Also, different lifestyle factors, such as the frequency of food consumption or time, in hours, spent outdoors during week or weekend, were not identified in this study as significantly influencing factors $(\mathrm{p}>0.05)$.

\section{DISCUSSION}

Results of this study confirmed that one of the main factors influencing vitamin D levels in children is season. Seasonal variation, with the lowest levels measured during October to March, has been observed in this study as well as worldwide among children and adults (10-15). It was shown that UV-B radiation is not strong enough during winter and spring time (October-March) to ensure sufficient synthesis of vitamin D in the skin, partly due to solar zenith angle, controlling potential UV B radiation. The Czech Republic lies from $\approx 48^{\circ} \mathrm{N}$ to $\approx 51^{\circ} \mathrm{N}$ and belongs to many regions of the world where is not possible to synthesize significant amounts of vitamin D3 in realistic exposure times for several months of the year (16). Moreover, there is no mandatory and only minimal voluntary vitamin D food fortification in the Czech Republic.

Apart from the above, there are also many other factors potentially affecting the ability to synthesize vitamin D3, including age, skin pigmentation, amount of skin exposed, time of the day, use of sunscreen, lifestyle or even air quality (10).

Previous studies that assessed age-related differences identified that adults had lower vitamin D levels than children, as cutaneous synthesis of vitamin D is decreasing with declining capacity of the skin itself to make cholecalciferol and also varies depending on the type of behaviour. However, the age of individuals when this decline occurs is unknown $(17,18)$. Our investigation showed that children's age is not significantly affecting the $25(\mathrm{OH}) \mathrm{D}$ levels (5-year-olds: $66.3 \mathrm{nmol} / \mathrm{L}$ versus 9-year-olds: $62.5 \mathrm{nmol} / \mathrm{L}$; $\mathrm{p}>0.05)$, which is in agreement with the systematic literature review of 2014 (19).

The relationship between $25(\mathrm{OH}) \mathrm{D}$ and gender was not significant ( $\mathrm{p}>0.05$ ) among our study subjects (boys $63.6 \mathrm{nmol} / \mathrm{L}$ versus

Table 2. Seasonal variation in serum $25(\mathrm{OH}) \mathrm{D}$

\begin{tabular}{|c|c|c|c|c|c|}
\hline & $\begin{array}{c}\text { Total } \\
\mathrm{N}=419\end{array}$ & $\begin{array}{l}\text { Spring } \\
n=124\end{array}$ & $\begin{array}{c}\text { Summer } \\
n=85\end{array}$ & $\begin{array}{c}\text { Autumn } \\
n=144\end{array}$ & $\begin{array}{c}\text { Winter } \\
n=66\end{array}$ \\
\hline GM (nmol/L) & 61.3 & 48.0 & 69.8 & 73.9 & 54.6 \\
\hline Median (nmol/L) & 63.0 & 49.8 & 67.8 & 79.0 & 56.0 \\
\hline P95 (nmol/L) & 104 & 86.4 & 113 & 113 & 93.9 \\
\hline Range (nmol/L) & $12.1-147$ & $12.1-104$ & $19.6-139$ & $21.2-147$ & $23.7-114$ \\
\hline Sufficiency (\%) & 34 & 14 & 40 & 57 & 15 \\
\hline Insufficiency (\%) & 40 & 36 & 48 & 33 & 52 \\
\hline Deficiency (\%) & 24 & 44 & 11 & 10 & 32 \\
\hline Severe deficiency (\%) & 3 & 6 & 1 & 1 & 2 \\
\hline
\end{tabular}

GM - geometric mean, P95 - 95th percentile. The calculated percentages were rounded off to the nearest whole number.

Table 3. Comparison of the available worldwide data with the current study

\begin{tabular}{|c|c|c|c|c|c|c|c|c|c|}
\hline Country & N & $\begin{array}{c}\text { Age } \\
\text { (years) }\end{array}$ & Season & $\begin{array}{c}\text { Method for } \\
\text { vitamin D } \\
\text { analysis }\end{array}$ & $\begin{array}{c}\text { Severe } \\
\text { deficiency } \\
(\%)\end{array}$ & $\begin{array}{c}\text { Deficiency } \\
(\%)\end{array}$ & $\begin{array}{c}\text { Insufficiency } \\
(\%)\end{array}$ & $\begin{array}{c}\text { Sufficiency } \\
(\%)\end{array}$ & Reference \\
\hline Czech Republic & 419 & 5 and 9 & All year & ECLIA & 3 & 24 & 39 & 34 & This study \\
\hline Europe* $^{*}$ & 1,006 & $12-17$ & October-July & ELISA & 15 & 27 & 39 & 19 & (20) \\
\hline Belgium & 357 & $4-11$ & February-June & RIA & 5 & 53 & 40 & 2 & (21) \\
\hline Greece & 43 & $3-10$ & All year & RIA & \multicolumn{2}{|c|}{40.3} & 35 & 24.7 & (22) \\
\hline Italy & 652 & $2-21$ & All year & RIA & 9.5 & 36.4 & 33.6 & 20.5 & (25) \\
\hline Norway & NA & $15-18$ & September-April & LC-MS/MS & 16.5 & 43.7 & 27.4 & 12.4 & (23) \\
\hline Netherlands & 4,167 & 6 & All year & LC-MS/MS & 6.2 & 23.6 & 36.5 & 33.7 & (24) \\
\hline USA & 1,855 & $6-11$ & All year & LC-MS/MS & 0.7 & 9.7 & 56 & 33.6 & (27) \\
\hline Canada & 1,898 & $1-5$ & All year & CLIA & 0 & 6 & 24 & 70 & (28) \\
\hline South Korea & 2,062 & $10-18$ & Al year & RIA & 13 & 55 & 28 & 4 & (26) \\
\hline
\end{tabular}

*HELENA study: Austria, Belgium, France, Germany, Greece, Hungary, Italy, Spain, and Sweden 
girls $62.2 \mathrm{nmol} / \mathrm{L}$ ) or in the sample populations of the eligible studies worldwide (19). However, in an Irish study of adolescents, girls had lower winter time mean serum 25(OH)D levels than boys although they had higher levels than boys during summer time. According to the authors, it might be related to the higher proportion of girls $(72 \%)$ than boys $(43 \%)$ being sampled in late summer (15). Gender as a significant predictor of the year-round vitamin D status was also observed in a nationally representative sample of New Zealand children and adolescents and in the US adolescents and adults $(13,20)$; nevertheless, the reason for this apparent gender difference remained unexplained.

As is known, vitamin D deficiency is a public health concern worldwide and is very common also in Europe $(21,22)$. The results of the current study were compared to selected available studies from Europe, North America and South Korea based on such parameters as the analytical method or sampling season. Nevertheless, it is important to note that there are many other potential factors which may influence the comparison across countries (23). As shown in Table 3, there are a few childrenbased European studies looking at the 25(OH)D levels according to the cut-off points used for evaluation. However, only a limited number of studies are available in children up to 10 years of age, which is also reflected in our comparison.

In the current study, we observed a high prevalence of $25(\mathrm{OH})$ D insufficiency or deficiency. Generally over half of the Czech children aged 5 and 9 years had serum 25(OH)D levels below 75 $\mathrm{nmol} / \mathrm{L}$ and $27 \%$ of them even below $50 \mathrm{nmol} / \mathrm{L}$, which might be explained by inadequate time spent outdoors and contemporary sedentary lifestyles. Similar results have been reported in 6-yearold children from the Netherlands, of whom $66 \%$ had $25(\mathrm{OH})$ D concentrations below the optimal levels and almost $30 \%$ of them were vitamin D deficient (24). In other European studies from Norway (22), Belgium (23), Greece (25), and Italy (26) there were even higher prevalence rates of vitamin D deficiency and insufficiency. The representative European study HELENA (Healthy Lifestyle in Europe by Nutrition in Adolescence) included 1,006 children aged 12 to 17 years from nine European countries. The study showed that $81 \%$ of the children had $25(\mathrm{OH})$ D concentrations below $75 \mathrm{nmol} / \mathrm{L}$ (20). In our comparison, the lowest values were observed among older children from South Korea (27). In that study, deficiency was observed in $68 \%$ of children and insufficiency in $28 \%$ of them. On the other hand, vitamin D status in American studies showed relatively higher values of vitamin $\mathrm{D}$, with only $10 \%$ of children from the USA (28) and $6 \%$ of the Canadian children (29) having the $25(\mathrm{OH})$ $\mathrm{D}$ levels below $50 \mathrm{nmol} / \mathrm{L}$. These results are in accordance with vitamin D food fortification practices, which are on a voluntary basis. Food fortification differs between the USA and Canada; nevertheless both are similar in providing fortified foods with proven efficacy (30).

\section{Strengths and Limitations of the Study}

The strength of this study is that it provides the first information on the vitamin D status of healthy Czech preschool and early school children and shows its seasonal variation.

The limitations are as follows: the respondents were not randomly selected, so the results cannot be extrapolated to the entire paediatric population. The serum $25(\mathrm{OH}) \mathrm{D}$ was only measured once per participant. Time spent outdoors was only assessed subjectively by parents filling in the questionnaire. The questionnaire was incompletely filled by several subjects whose data concerning use of dietary supplements or maternal education were missing (Table 1). The type and quantity of dietary supplements used by children have not been specified. Differences in length of stay outdoors between girls and boys were not evaluated for reasons of the subjective nature of these data.

\section{CONCLUSIONS}

Vitamin D deficiency is a public health concern in the Czech Republic as two thirds of the Czech children have a suboptimal vitamin D status during the whole year. The knowledge of possible determinants is of importance for the development of public health strategies for the prevention of vitamin D deficiency. As expected, this study indicated a significant contribution of the sampling month. In the period from October to April; it is essential to use vitamin D supplements for the reduction of risk for vitamin $\mathrm{D}$ deficiency, as the sun exposure is lower than during other months under the conditions of the Czech Republic. Children are a sub-population particularly vulnerable to low vitamin D status, thus we consider very important to monitor vitamin D saturation across the country also in the future as a part of the Czech Human Biomonitoring System. Further monitoring will be needed to characterize of vitamin D status in the Czech population.

\section{Acknowledgement}

This research was funded by the Ministry of Health. The authors thank their colleagues from the Regional Public Health Institutes for their valuable help in conducting the study. Acknowledgments also include GPs for children and adolescents who have collaborated on recruiting and blood sampling. They also gratefully acknowledge all children and their parents for their collaboration with the study and voluntary donation of biological samples.

\section{Conflict of Interests}

None declared

\section{Adherence to Ethical Standards}

The study protocol was approved by the Ethical Committee of the National Institute of Public Health. Written informed consent was obtained from all parents.

\section{REFERENCES}

1. Černá M, Puklová V, Hanzlíková L, Sochorová L, Kubínová R. 25 years of HBM in the Czech Republic. Int J Hyg Environ Health. 2017 Mar;220(2 Pt A):3-5.

2. Dort J, Bayer M, Dortová E, Hadravová V. Vitamin D and other parameters of calcium and phosphate metabolism in healthy term newborns after birth. Osteol Bull. 2007;12(2):70-3. (In Czech.)

3. Palacios C, Gonzalez L. Is vitamin D deficiency a major global public health problem? J Steroid Biochem Mol Biol. 2014;144 Pt A:138-45.

4. Bischoff-Ferrari HA, Giovannucci E, Willett WC, Dietrich T, DawsonHughes B. Estimation of optimal serum concentrations of 25-hydroxyvitamin D for multiple health outcomes. Am J Clin Nutr. 2006;84(1):18-28.

5. Holick MF. Sunlight and vitamin D for bone health and prevention of autoimmune diseases, cancers, and cardiovascular disease. Am J Clin Nutr. 2004 Dec;80(6 Suppl):1678S-88S. 
6. Pludowski P, Holick MF, Grant WB, Konstantynowicz J, Mascarenhas MR, Haq A, et al. Vitamin D supplementation guidelines. J Steroid Biochem Mol Biol. 2018 Jan;175:125-35.

7. Mansbach JM, Ginde AA, Camargo CA Jr. Serum 25-hydroxyvitamin D levels among US children aged 1 to 11 years: do children need more vitamin D? Pediatrics. 2009 Nov;124(5):1404-10.

8. Cashman KD, Dowling KG, Škrabáková Z, Gonzalez-Gross M, Valtueña $\mathrm{J}$, De Henauw S, et al. Vitamin D deficiency in Europe: pandemic? Am J Clin Nutr. 2016 Apr;103(4):1033-44.

9. Fitzpatrick TB. The Validity and practicality of sun-reactive skin types I through VI. Arch Dermatol. 1988 Jun;124(6):869-71.

10. Rovner AJ, O'Brien KO. Hypovitaminosis D among healthy children in the United States: a review of the current evidence. Arch Pediatr Adolesc Med. 2008 Jun;162(6):513-9.

11. Kull M Jr, Kallikorm R, Tamm A, Lember M. Seasonal variance of 25$(\mathrm{OH})$ vitamin $\mathrm{D}$ in the general population of Estonia, a Northern European country. BMC Public Health. 2009 Jan 19;9:22. doi: 10.1186/1471-24589-22.

12. Pasco JA, Henry MJ, Nicholson GC, Sanders KM, Kotowicz MA. Vitamin D status of women in the Geelong Osteoporosis Study: association with diet and casual exposure to sunlight. Med J Aust. 2001 Oct 15;175(8):4015.

13. Rockell JE, Green TJ, Skeaff CM, Whiting SJ, Taylor RW, Williams SM, et al. Season and ethnicity are determinants of serum 25-hydroxyvitamin D concentrations in New Zealand children aged 5-14 y. J Nutr. 2005;135(11):2602-8.

14. Viljakainen HT, Palssa A, Kärkkäinen M, Jakobsen J, Cashman KD, Mølgaard C, et al. A seasonal variation of calcitropic hormones, bone turnover and bone mineral density in early and mid-puberty girls - a cross-sectional study. Br J Nutr. 2006;96(1):124-30.

15. Hill TR, Cotter AA, Mitchell S, Boreham CA, Dubitzky W, Murray L, et al. Vitamin D status and its determinants in adolescents from the Northern Ireland Young Hearts 2000 cohort. Br J Nutr. 2008;99(5):1061-7.

16. Hossein-nezhad A, Holick MF. Vitamin D for health: a global perspective. Mayo Clin Proc. 2013 Jul;88(7):720-55.

17. Stein EM, Laing EM, Hall DB, Hausman DB, Kimlin MG, Johnson MA, et al. Serum 25-hydroxyvitamin D concentrations in girls aged 4-8 y living in the southeastern United States. Am J Clin Nutr. 2006;83(1):75-81.

18. Heaney RP. Barriers to optimizing vitamin D3 intake for the elderly. J Nutr. 2006;136(4):1123 -5.

19. Hilger J, Friedel A, Herr R, Rausch T, Roos F, Wahl DA, et al. A systematic review of vitamin D status in populations worldwide. Br J Nutr. 2014; 111(1):23-45

20. Looker AC, Dawson-Hughes B, Calvo MS, Gunter EW, Sahyoun NR. Serum 25-hydroxyvitamin D status of adolescents and adults in two seasonal subpopulations from NHANES III. Bone. 2002;30(5):771-7.
21. González-Gross M, Valtueña J, Breidenassel C, Moreno LA, Ferrari M, Kersting M, et al. Vitamin D status among adolescents in Europe: The Healthy Lifestyle in Europe by Nutrition in Adolescence study. Br J Nutr. 2012;107(5):755-64.

22. Öberg J, Jorde R, Almås B, Emaus N, Grimnes G. Vitamin D deficiency and lifestyle risk factors in a Norwegian adolescent population. Scand $\mathrm{J}$ Public Health. 2014 Nov;42(7):593-602.

23. Sioen I, Mouratidou T, Kaufman J, Bammann K, Michels N, Pigeot I, et al. Determinants of vitamin D status in young children: results from the Belgian arm of the IDEFICS (Identification and Prevention of Dietaryand Lifestyle-Induced Health Effects in Children and Infants) Study. Public Health Nutr. 2012;15(6):1093-9.

24. Voortman T, van den Hooven EH, Heijboer AC, Hofman A, Jaddoe VW, Franco $\mathrm{OH}$. Vitamin D deficiency in school-age children is associated with sociodemographic and lifestyle factors. J Nutr. 2015 Apr;145(4):791-8.

25. Lapatsanis D, Moulas A, Cholevas V, Soukakos P, Papadopoulou ZL, Challa A. Vitamin D: a necessity for children and adolescents in Greece. Calcif Tissue Int. 2005;77(6):348-55.

26. Vierucci F, Del Pistoia M, Fanos M, Gori M, Carlone G, Erba P, et al. Vitamin D status and predictors of hypovitaminosis D in Italian children and adolescents: a cross-sectional study. Eur J Pediatr. 2013 Dec;172(12):1607-17.

27. Kim SH, Oh MK, Namgung R, Park MJ. Prevalence of 25-hydroxyvitamin $\mathrm{D}$ deficiency in Korean adolescents: association with age, season and parental vitamin D status. Public Health Nutr. 2014 Jan;17(1):122-30.

28. Schleicher RL, Sternberg MR, Looker AC, Yetley EA, Lacher DA, Sempos CT, et al. National Estimates of Serum Total 25-Hydroxyvitamin D and Metabolite Concentrations Measured by Liquid ChromatographyTandem Mass Spectrometry in the US Population during 2007-2010. J Nutr. 2016;146(5):1051-61.

29. Maguire JL, Birken CS, Khovratovich M, Degroot J, Carsley S, Thorpe KE, et al. Modifiable dterminants of serum 25-hydroxyvitamin D status in early childhood: opportunities for prevention. JAMA Pediatr. 2013 Mar 1;167(3):230-5.

30. Calvo MS, Whiting SJ. Survey of current vitamin D food fortification practices in the United States and Canada. J Steroid Biochem Mol Biol. 2013;136:211-3

Received May 21, 2018 Accepted in revised form October 29, 2018 